\title{
Günlük yaşamda kadınlar arası mizah ilişkilerine antropolojik bir yaklaşım
}

\author{
Barış İş̧̧i Pembeci ${ }^{*}{ }^{*}$ \\ 'Dr. Öğr. Üyesi | Muğla Sıtkı Koçman Üniversitesi, Edebiyat Fakültesi, Sanat Tarihi Bölümü, Muğla - Türkiye
}

Alındı/Received: 13 Nisan / April 2021 | Düzeltildi/Revised: 19 Haziran / June 2021 | Kabul/Accepted: 26 Haziran / June 2021 | Yayımlandı/Published: 28 Haziran / June 2021

\section{Öz}

Bu çalışmada mizahın antropolojik çalışmalarda ciddiye alınması gerektiği iddiasından yola çıkılarak günlük yaşamın kültürel bir öğesi olması ötesinde mizahın toplumsal cinsiyet, sosyal ilişkiler, otorite ve statü gibi daha genel konuları anlamada kilit görev üstlendiği gösterilmeye çalışılmıştır. Antropolojik mizah çalışmalarının temelini oluşturan mizah teorileri incelenmiș ve bu teorilerden faydalanarak ama mizahın günlük yaşamda üretilme, paylaşılma ve tüketilme biçimlerini analiz etmede daha kullanışlı olabilecek bir teorik çerçeve çizilmeye çalışılmıştır. Bu teorik çerçeve içerisinde Muğla kentinin dağlık köyü Yeniköy'de kadınlar arası mizah ilişkileri sosyal ve güç ilişkileri içinde devam eden günlük yaşam bağlamında incelenmiştir. Mizahın yaşadıkları toplumda marjinal bir pozisyonda bulunan kadınlar için bir eylemlilik alanı yarattığı ve kadınların bu alanda mizahı yaratıcı bir direniş taktiği olarak kullandığı iddia edilmiştir. Dünyada antropolojik mizah çalışmaları artarken Türkçe mizah çalışmalarında mizahın sosyal günlük yaşamın önemli boyutlarına ıșık tutma potansiyeli henüz keșfedilememiștir. Bu çalışma günlük yaşamda yoğun bir fiziksellik içeren, kişisel ve sosyal bedende akseden mizahı incelemede antropolojinin uzun dönem katılımcı gözlem, yerel bağlama yoğunlaşma ve deneyim-temelli yaklaşımı ile bu eksiği doldurmaya yönelik bir girişimdir.

Anahtar sözcükler: Mizah, şakalaşma, günlük yaşam, mizah antropolojisi

\section{Giriş}

"Bir toplumu anlamake için ekonomike veya demografik istatistiklerini çalışabilirsiniz: Ya da şakalarm toplarsmız:"

(Driessen, 2016, s. 141)

Evrensel bir insan davranışı olması ve günlük yaşantıdaki önemi ve yeri düşünüldügünde mizahın bilimsel dikkati yeterince çekmemiş olması ilginçtir. Mizahın antropolojinin ilgisini çekmesi diğer bilimlere göre daha da gecikmiş ve antropologlar ancak 1980'lerde mizahı başlı başına araştırılması gereken bir konu olarak görmeye başlamıştır (Apte, 1985, s. 9). Antropolojideki mizaha karşı olan bu kayıtsızlık diğer bilimlerin

\section{An anthropological approach to humor relations between women in everyday life}

\section{Abstract}

This paper argues that humor should be taken seriously as it plays a key role in understanding larger issues such as gender relations, social interactions, power, and status in a society. Acknowledging its significance as more than a cultural object, the paper first focuses on the theoretical approaches to bumor in anthropology and then constructs a conceptual framework by adding to these theories a new approach that treats the production, sharing and consumption of bumor in daily life more effectively. Following this novel theoretical framework, bumor interactions among women of a mountainous village of Yeniköy in the city of Muğla are analyzed by positioning them within the context of social and power relations in everyday life. The argument of the analysis is that humor creates a space of agency for the women of Yenikëy who occupy a marginal space in their society and that these women creatively manipulate humor as a tactic for resisting existing power structures. As anthropological studies of humor are increasing in the world, Turkish studies on bumor are yet to discover the potential of humor in pointing out important dimensions of everyday life. This study aims to contribute to such studies in Turkey through an analysis of the physicality of humor and the way it resonates through the individual and social body through a long-term participatory observation, and a localized and experience-based investigation.

Key words: Humor, joking, everyday life, anthropology of humar

kayıtsızlığından daha da ilginçtir çünkü disiplinin kurucularından Malinowski antropolojiyi "mizah duyusunun bilimi" olarak tanımlamıştır (Driessen, 2016, s. 142). Dwyer'ın (2009) dikkat çektiği gibi diğer önemli bir antropolog olan Geertz'in antropologlara siklikla "küçük gerçekler" diye tanımladığ1 günlük yaşamın ayrıntılarına önem vermeleri ve bu "küçük gerçekleri" "büyük meselelere" bağlama çağrısı yapmış olmasına rağmen bizzat kendisinin önerdiği tanıma uyan mizahı gözden kaçırmış olması dikkat çekicidir (s. 404). Apte (1988, s. 8), antropologların odaklandıkları çok sayıdaki konulara, yöntemlere, teorilere rağmen mizaha uzak durmalarının sebeplerinden birinin mizahı araştırmaya değer bulmamaları olabileceğini iddia eder (s. 8). Fine 
(1985) ise sebep olarak mizahın oyun gibi anlaşılması ve tarifi zor bir kavram olmasını gösterir (s. 160). Son y1llarda oldukça artan antropolojik çalışmaya rağmen mizahın nasıl tanımlanması gerektiğine dair ortak bir kararın olmaması bu iddiay1 kantllar niteliktedir.

$\mathrm{Bu}$ yazıda iddia edileceği üzere mizah başlı başına zengin bir araştırma konusu olmalıdır çünkü mizah bir toplumdaki yerel normlara, karşıtlıklara ve tabulara 1şık tuttuğu gibi sosyal eşitsizlikleri ve güç ilişkilerini anlamamıza da yardımcı olur. Mizahın bağlamsal, oldukça karmaşık ve hatta tutarsız olma özellikleri onun farkl biçimlerine, işlevlerine ve etkilerine odaklanan çok boyutlu ve ayrıntılı bir analize, yani etnografik incelemeye tabi tutulmasını gerektirir. Çalışmanın ilk bölümünde mizah çalışmalarında antropolojiye özgü yaklaşımlar detaylı bir şekilde değerlendirilecek, mizahı anlama ve tanımlama girişimleri incelenecektir. Bu kısmın amacı mizahın sosyal günlük yaşamın önemli boyutlarını anlamamızda bakış açıları sunabilme potansiyelinden ötürü etnografik çalışmaların önemli bir parçası veya tek başına bir araştırma konusu olması gerektiğini göstermektir. Mizah üzerine yapılan Türkçe araştırmaların referans olarak sadece Türkçeye çevrilebilmiş az sayıdaki kaynağı kullanmaları daha ayrıntılı bir İngilizce literatürün tanıtımına ihtiyac1 göstermektedir. Yazının ikinci bölümünde ise mizah çalışmalarında kullanılabilecek bir teorik çerçeve geliştirilecek ve bu teorik çerçeve içinde Muğla'nın bir köyünde kadınlar arasındaki mizaha odaklanan on aylık etnografik bir alan çalışması örneği verilecektir. Günlük yaşamda mizahın üretilme ve tüketilme biçimleri açılanacak ve mizahın kadınları köyde marjinal bir pozisyonda tutan güç ilişkilerinin dışına çıkabilmelerini, kadınların bu marjinal pozisyonlarında yaratıcı direniş taktikleri geliştirebilmelerini sağladığı gösterilecektir. $\mathrm{Bu}$ bölümün amacı mizahın kültürel bir öğe olarak incelenmesinin ötesinde günlük yaşamda üretilme, paylaşılma ve tüketilme süreçlerinin incelenmesinin toplumsal cinsiyet ve güç iliş kileri gibi daha genel konuları anlamada ne kadar önemli olabileceğini göstermektir.

\section{Mizah ve antropoloji}

Antropoloji disiplinin mizaha tarihsel olarak uzak durmuş olması ve bu kayıtsızlığın mizahın insan deneyiminin merkezinde ve antropolojinin mizahı analiz edebilecek donanıma sahip olmasına rağmen gerçekleşmiş olması çok sayıda antropoloğun dikkatini çekmiş bir durumdur (örn. Osella ve Osella, 1998; Carty ve Musharbash, 2008; Trnka, 2011). 1980’lerden önce mizahı ve gülmeyi ciddi bir şekilde ele alan ve bu konuda bir bilimsel makale veya kitap yazan çok az sayıda araştırmacı bulunmaktadır (Carty ve Musharbash, 2008 , s. 212). Antropolojinin mizah üzerine klasik diyebileceğimiz eserleri arasında Radcliffe-Brown'ın şakalaşma ilişkileri üzerine yazılarını (1940, 1949), Mary Douglas'in “Şakalar" makalesini (1970), Basso'nun batı Apaçilerin beyazlar üzerine şakalarını inceleyen çalışmasını (1979) ve Handelman'ın yine şakalaşma üzerine olan çalışmasını (1972) gösterebiliriz. Bunların dışında birkaç araştırmacı da başka konulara odaklanan etnografik çalışmalarında mizaha sınırlı bir yer vermekle yetinmişlerdir (Carty ve Musharbash, 2008, s. 212).

Mizah ve gülme üzerine asıl çalışma konusu olarak odaklanan ciddi çalışmalar antropoloji dışında felsefe ve psikoloji gibi disiplinler tarafindan üretilmiştir. Mizah araştırmalarında klasik felsefeciler olarak Aristoteles'ten ve Hindu mantıkçılardan başlayan ve Hobbes, Descartes, Schopenhauer ile devam eden bir akımı saptayabiliriz. Mizahı ciddi bir araştırma konusu olarak ele almıs olan psikolojiden sayabileceğimiz isimleri de Freud'dan başlayarak, Bergson, Eastman, Berger, Grotjhan, Koestler, Legman ve Monro olarak stralayabiliriz. Apte (1988) mizaha olan bilimsel ilginin 1970’lerden itibaren ivme kazandığına ve bunun sebebinin mizahın çok yaygın bir insan deneyimi ve son derece çeşitlilik sergilemesi olabileceğine dikkat çeker (s. 8). Felsefe, edebi eleştiri, edebiyat tarihi, sosyoloji, folklor çalışmaları, psikoloji gibi disiplinler mizah üzerine odaklanarak şu soruların cevaplarını aramışlardır: Mizah neden ve nasıl vuku bulur? Hangi sosyal ortamlarda mizah ortaya çıkar? Mizah hangi formlarda görülür? Sosyal-kültürel temelleri nelerdir? Mizahı kim, neden başlatır? Mizahı kim anlayabilir veya takdir edebilir? Kimler mizahtan etkilenir, mizahın icra edilmesinde ne teknikler kullanılır? Mizahın işlevleri nelerdir?

Farklı disiplinler tarafından geliştirilen, günümüzde mizah çalışmalarını beslemeye devam eden ve antropolojik yaklaşımların da faydalandığı başlıca mizah teorilerini şu gruplar halinde inceleyebiliriz.

Rahatlama teorisi çok daha karmaşı olmasına rağmen en basit haliyle mizahın psikolojik bir gerilim durumunda olan insanları rahatlattığını ve bu gerilimden kurtulmalarını sağladığını iddia eder (Musharbash, 2008, s. 271). Gülme bu rahatlamanın bir işaretidir (Freud, 1963; Critchley, 2002). Teorinin kurucusu Freud, mizahın bastırılmış bir fikrin doğduğu durumlarda vuku bulduğunu, bilinçli durumumuzu bozduğunu ve gerilimin hazla salıverilmesini sağladiğını söyler. Diğer bir deyişle, insanlar bilinçli algılarını devamlı bir süzgeçten geçirmek durumundadırlar ve bunun için de bilinçdışılarını denetlemek için enerji harcarlar. Mizah işte bu kontrolü bozar ve denetleme sistemine mola aldırır. Bir süreliğine de olsa bilinçdışı kısıtlama olmadan rahat birakilır, mizah ile gelen rahatlama ve özgürlük hissinin sebebi de budur. Freud, benzer açıklamayı rüyalar1 yorumlamada da kullansa da şaka ile rüya arasında önemli bir ayrım yapar. Şaka, rüyadan farklı olarak bir kişiden diğerine iletilir. Yani yapılan şakanın 
başka biri tarafindan anlaşılabilir olması gerekir ve bu yüzden de mizahın çarpıtılmış fikirler içermesi kısıtlı olmak zorundadır (Freud, 1963, s. 173-179).

Freud'un mizah üzerine bu teorik yaklaşımını sosyal bağlamda, insan davranışlarını izleyerek takip eden etnografik örneklerden bir tanesi Dundes'in 1rkç1 şakalar üzerine yaptığı çalışmasıdır. Dundes'a göre 1rkç1 mizah özellikle etnik olarak "öteki" olana karşı duyulan saldırgan hisleri ve endişeleri ifade etme işlevi görür. Fiziksel saldırganlı̆̆ın yasak olması veya başka sebeple imkânsız ya da istenmez olduğu durumlarda şaka yoluyla düşman kabul edilen kişi veya kişiler küçültülür, hor görülür ve saldırganlık risksiz bir şekilde ifade edilmiş olur (Dundes, 1987). Benzer şakalar bask1 altında tutulan azınlık durumundaki insanlar gibi güçsüz kişiler tarafindan yapıldığında da benzer bir durum görülür. Azınlık durumunda olan kişilerin güç sahibi olanları hedef alan şakalar yapması aşağılama amacı taşımasının yanında güçlü karşısında otorite kazanma memnuniyeti de sağlar. Diğer bir deyişle, mağduriyete karşı hissedilen gerilim dalga geçme yoluyla atlatılır fakat bu dalga geçmenin var olan güç ilişkilerini etkileme kabiliyeti yoktur (van Roekel, 2016, s. 67).

Freud'un mizahın gerilim, bask1 ve diğer olumsuz duygulardan kurtulmayı sağladığ1 yönündeki teorisi bazı araştırmacıların mizahın özgürleştirici etkisine ileri derecede odaklanmasina sebep olmuştur (Trnka, 2011, s. 340-341). Bu araştırmacılardan birisi Mary Douglas'tır. Douglas (1968) mizahın özgürleştirici etkisini daha da genişletirve mizahın baskıcı sosyal normları bozucu etkisi olduğunu, güç ilişkilerini sarsıcı bir rol üstlendiğini iddia eder (s. 365). Douglas'a göre mizah dinleyici durumunda olan bireyin sahip olageldiği zihinsel kategorilerini ve beklentilerini bozar ve bilişsel bir yeniden düzenlemeyle dinleyici bakış açısını değiştirir. Douglas (1975) bundan da ileri giderek şakanın veya mizahın ayin-karşıtı olduğunu iddia eder ve canlandırıcı bir genel kalıplardan kurtulma, özgürleşme hissi sunduğunu söyler (s. 96). Mizahın ve şakaların ayinden farklı olduğunu ve ayinin düzen ve harmoni dayattığını, şakanın ise bu düzeni bozduğunu ve alternatif bir düzen ifade ettiğini iddia eder. Standard bir ayin sosyal yaşamın dikte edilmiş örüntülerinin kaçınılmaz olduğunu dayatırken, mizahın mesaj1 bunlardan kaçışın mümkün olduğudur. Mizah doğası gereği karşıt-ayindir (Douglas, 1975, s. 103).

Douglas, mizahın bozguncu, yeniden düzenleyici ve hiyerarşiye saldırıcı etkilerine odaklanırken, mizah anı sonrasında neler olduğu konusunda sessizdir. Mizah bittiğinde ve düzen hissi geri geldiğinde ne olur? $\mathrm{Bu}$ sorunun cevabını şiddetli belirsizlik ve politik ve sosyal kaos altında yaşayan toplumlarda çalışmalar yapan antropologlar farklı şekillerde vermişlerdir. Mesela Trnka (2011) sosyal ilişkilerin keskin bir şekilde bozulduğu Fiji'de etnik şiddet ortamında mizaha odaklanan çalışmasında mizahın sadece bozguncu olmadığını ama aynı zamanda tehdit altında olan "istikrar" ve "normal" hissini de vurguladığını gösterir (s. 341). Mizah ve şaka üzerine olan antropolojik çalışmaların daha çok istikrarlı toplumlarda yapıldığını, mizahın sosyal kriz zamanlarındaki işlevine de odaklanılması gerektiğini iddia eden Trnka'ya göre mizah ve şaka var olan sosyal normları sorgulamaya sebep olurken üstü kapalı bir şekilde bu ilişkilerin devam ettiğini ve yaşamın tutarsız olma olasıllğının sinırlı olduğunu hissettirir. Benzer şekilde, Yeni Zelanda yerlileri olan Maori'lerle yaptığ1 etnografik çalışmada Schwimmer yok olma veya asimile olma tehdidi altında olan bir kültürün hayatta kalmasında mizahın rolünü incelemiştir (Cardeña ve Littlewood, 2006, s. 290). Kronik mağduriyet, tarihsel dışlanma durumundaki kültürlerde mizahın rahatsız edici deneyimleri yumuşatma özelliğine dikkat çekmekte ve kaos içindeki toplumlarda mizahın korku, belirsizlik ve acizlik deneyimleriyle şekillendiğini göstermektedir (Cardeña ve Littlewood, 2006, s. 291).

Üstünlük teorisi ise mizaha farklı bir açıdan yaklaşır ve mizahın bir başkasına veya duruma karşı hissedilen üstünlük hissinden doğduğunu iddia eder. Keith Speigel'e göre diğerlerinin saçma ve ahmak hareketlerine gülmek önemli insan deneyimlerindendir ve kendimizi diğerlerine göre daha az ahmak, daha az çirkin, daha az şanssız veya daha az güçsüz gibi olumlu şekilde kiyasladığımızda haz hissederiz (Pollio, 1985, s. 224). Üstünlük teorisi bu yaklaşımıyla mizahın dışlayıcı işlevine gönderme yapar. Yani, insanlar başkalarının şansızlığına gülerek aslında bir üstünlük hissi kazanırlar. Şaşırtıcı bir şekilde, etnografik çalışmalar göstermiştir ki, mizahın üstünlük hissini yaratma işlevi toplumdaki mağdur durumundaki insanlar tarafindan da sahiplenilir. Mesela Burma'nın siyah Amerikalıların kullandığı şakaları inceleyen çalışması, şakaların siyahlar için baskın durumdaki beyazlara karşı bir üstünlük hissi sağladığını ve aynı zamanda toplumdaki yerlerinin farkına varmalarına yol açtığını söyler (Trnka, 2011, s. 338). Mizah birlikte gülenleri birbirine yakınlaştırırken, mizahın hedef aldığı ötekini dışlar ve ötekiyle araya bir sinır çizer (Beckett, 2008).

Son yıllarda yapılan antropolojik çalışmalar mizahın güçle ve dışlamayla olan ilişkisine daha yakından bakmaya başlamışlar ve daha eleştirel bir yaklaşım önermişlerdir (Billig, 2005; Lewis, 2006; Lockyer ve Pickering, 2008). Mizahın, neşe, rahatlama gibi olumlu yönlerine vurgun yapan teorilerden farklı olarak mizahin nasil incitme, sinirlendirme gibi olumsuz duygulara yol açacağına dikkat çekilir. Bu yaklaşım, olumlu yönlerini yadsımazken, mizahın aynı zamanda karanlık bir yanının olduğunu ve neşeli maskesinin altında nasıl kontrol, disiplin ve hasımlık aracı olarak da kullanılabileceğine dikkat çeker. Mesela, Güney Hindistan'da Tamillerle 
yaptığı çalışmada dini ritüellerde şakalaşma ilișkilerini inceleyen Seizer (1997), bu şakalaşmaların var olan sosyal normları bozguna uğratmadığı gibi cinsiyet ilişkilerindeki eşitsizliği devam ettirdiğini ve hatta güçlendirdiğini iddia eder. Yani, bu toplumda mizah güçsüze güç vermek yerine güçlünün üstün olduğunu hatırlatır ve dolayısıyla bozgunu değil uyumluluğu vurgular. Seizer (1997), mizahın nasıl ve neden bazı koşullarda bozguncu, bazen de nasıl ve neden kültürel hegemonyanın bir aracı olarak kullanılabildiğini anlamak gerektiğini söyler (s. 63).

Mizah üzerine çalışmalarda en çok vurgulanan özelliklerden biri mizahın güçsüzler için sorunlarla nasıl bir baş etme aracı olabileceğidir. Mizah, Scott'ın (1985) "güçsüzün silahı" kavramına uyarlanmış ve acı çeken, korku ve güvensizlik hissi yaşayan insanlar için direniş imkânı, mekânı ve firsatı sunduğu iddia edilmiştir. $\mathrm{Bu}$ yaklaşımlarda mizah güçlüye tabi olarak yaşayan insanlar için şiddet içermeyen bir direniş ifade etme ve hegemonik statükoyu etkileme imkânı veren sembolik bir mekân yaratır. Mesela Basso keskin bir ırkç1lıkla yüz yüze yaşamak zorunda olan Apaçi Amerikan yerlileriyle çalışmış ve beyazları hedef alan şakaların bu insanlar için bir grup dayanışması hissini ve öz saygılarını kaybetmemelerini sağladığını göstermiştir (Trnka, 2011, s. 338). Mizah üzerine en etkili olmuş çalışmalardan birini yapmış olan antropolog Goldstein de (2013) mizahın güç ilişkilerini sorgulamaya yol açan kültürel bir direniş aracı olabileceğinin altını çizer. Brezilya'nın Rio de Janeiro şehrinde kadınların mizah pratiklerini incelediği çalışmasında mizah yoluyla kadınların sürekli bir şekilde maruz kaldıkları şiddet ve baskı ortamında nasıl yaratıcı bir duygusal rahatlama yaşadıklarının altını çizer.

Mizahı politik söylemin ve sosyal anlatımların bir formu olarak inceleyen çalışmaların da sayısı son yıllarda artmıştır. Graeber (2009), mesela, mizahın siyasî gösteriler yaratmadaki gücünü analiz ederken, Boyer ve Yurchak (2010) olagelen siyasî muhalefetin bozguna uğradığı yerde mizah başarılı olur ve siyasî elitleri eleştiride kullanılabilir diye iddia eder. Diğer araştırmacılar da baskıcı rejimlerde mizahın bir siyasî silah olarak kullanılabileceğinin örneklerini vermişlerdir (Makar, 2011; Colla, 2013; Dağtaş, 2016).

\section{Gereç ve Yöntem}

Evrensel bir insan davranış olan ve üretiminden tüketimine farklı dinamikler barındıran mizah üzerine yapılan antropolojik çalışmalar gösteriyor ki antropologlar mizaha giderek daha fazla ilgi göstermeye başlamış ve onu marjinal bir araştırma nesnesi olmaktan çıkarıp başlı başına bir araştırma konusu olarak incelemeye başlamışlardır. Çünkü mizah psikolojinin ve bilişsel disiplinlerin indirgeyici olabilen yaklaşımından çıarılıp antropologların uzman oldukları sosyal bağlamına alındığında kültürün önemli bir öğesi olduğu ortaya çıkmıştır. Antropologlar mizahın günlük hayatın bir verisi olduğunu ama aynı zamanda toplumsal cinsiyet, güç ilişkileri, etnik ayrımcilık gibi daha genel konuları anlamada da önemli olabileceğini fark etmişlerdir.

Antropologlarin mizaha artan bu ilgisi maalesef Türkiye'de karşıllı̆̆ını bulamamıştır. Türkiye'deki mizah üzerine çalışmalara baktığımızda daha çok fikralara ve mizah dergilerine yoğunlaşıldığını (Türkmen, 2019, s. 419), mizahın günlük yaşamda üretilme, paylaşılma ve tüketilme süreçlerinin incelenmesinin çok eksik olduğunu görmekteyiz. Son yillarda mizahın siyasî protestoda kullanılma biçimlerine odaklanan çalışmalar artsa da (örn. Eker Öğüt, 2009; Dinç, 2012; Eken, 2014; Görkem, 2015; Gürcan ve Peker, 2015; Gürel 2015; Dağtaş 2016), günlük yaşamda yoğun bir fiziksellik içeren, kişisel ve sosyal bedende akseden mizahı incelemede antropolojinin uzun dönem katılımc1 gözlem, yerel bağlama yoğunlaşma ve deneyim-temelli analizi hala çok yetersizdir. Bu çalışma Türkiye'deki bu eksiği doldurmaya yönelik bir girişimdir.

Muğla kentinin dağlık köyü Yeniköy'de kadınlar arası mizah ilişkileri sosyal ve güç ilişkileri içinde devam eden günlük yaşam bağlamında incelenecek ve mizahın marjinal bir pozisyonda kadınlar tarafindan nasıl yaratıcı bir direniş taktiği olarak kullanıldığ1 gösterilmeye çalışılacaktır. Kadınların günlük hayatta planlı veya plansız buluşmalarında gerçekleşen mizahı incelemedeki amaç şakaların kendisine odaklanmaktan ziyade bu mizahın ve mizah algisının içinde yer aldığı ve beslendiği yerel cinsiyet ve güç ilişkilerine nasıl $1 s ̧ 1 k$ tuttuğunu anlamaya çalışmaktır. Mizaha odaklanarak aslında kadınların günlük yaşamlarında etkili olan otorite, statü ve cinsiyet gibi konulara ve mizahın bu kadınlar için günlük yaşamdaki kısıtlayıcı ve hatta şiddet içeren ilişkiler ile başa çıkma aracı görevi gördüğüne dikkat çekilecektir. Kadınları güldüren ve eğlendiren şakaların aslında bu kadınları neyin üzdüğünü, acıttığını ve bastırdığını anlamada yardımcı olabileceği gösterilmeye çalış1lacaktır.

Yazar için mizaha bu ilginin başlangıc1 2010 yılında Kırgizistan'da tamamen farklı bir konuda yapilan alan çalışması sırasında başlamıştır. Özellikle kadınlar ile erkekler arasındaki şakalaşma, paylaşılan mizahta keskin rol dağglımları olduğu fark edilmiş ve özellikle erkeklerin herhangi bir ortamda kadınları şaka yaparak güldürme gibi bir görev üstlenmiş olmaları dikkat çekmiştir. Fakat asıl tez konusunun dışına çıkılamamış ve mizahı özel olarak inceleme işi sonraya birakılmıştı. Aradan on yıl geçtikten sonra mizaha yeni bir ilgi duyulmaya başlaması yine farklı bir konuda, 2020 yılında kadın arıcilar üzerine yapılan alan çalışması ile başlamıştır. Muğla Yeniköy'de kadınların günlük yaşamının paylaşıldığı 2020 yılının Ocak-Kasım ayları arasında süren on aylık 
alan çalışması sırasında kadınlar ve kadınlar ile erkekler arasında ortaya çıkan mizah anları ve alanları bu sefer mizahı merkeze alacak bir etnografik çalışmanın konusu olmuştur. Bu amaçla, mizah ilişkileri, mizahın oluşma anları, paylaşımı, ortamları, şakaların kim tarafindan nasıl üretildiği, hedef alınan kişiler ve etkileri yakından gözlemlenmeye başlanmıştır. Köyün kadınlarıyla ev gezmelerinde, pazarlarda, günlük karşılaşmalarda, zeytin ve bal hasatlarında, düğünlerde bir araya gelinmiştir. $\mathrm{Bu}$ katılımcı gözlemlerin dışında on iki kadın ve beş erkekle derinlemesine mülakat yapılmıştır. Alan çalışması sırasında bu çalışmada odaklanılan aileye komşu olarak yaşamıs olmak hem bu kişileri daha yakından tanıma hem de mizah ortamlarına daha siklikla ve yakından şahit olma olanağı sağlamıştır. Yazının bundan sonraki bölümünde ilk olarak mizahın günlük yaşamda üretilme, paylaşılma ve tüketilme biçimlerini analiz etmek için inşa edilen teorik çerçeve açıklanacaktır. Sonrasında ise bu teorik çerçeve içinde Gülnaz, Emine ve Sinan rumuz adlarıyla isimlendirilen üç karakter arasındaki mizahla şekillenen ilişki ve mizahın üretilme ve tüketilme dinamiklerini çarpıcı şekilde gösteren bir buluşma ayrınt1lı olarak incelenecektir.

\section{Kuramsal çerçeve}

Bu çalışmada takip edilen kuramsal yaklaşım mizahı şakayı yapan ve bu şakanın seyircisini içeren bir sosyal pratik olarak kabul eder. Yani, mizah kendi başına bir kültürel ürün değil, bir topluluktaki ortak anlayışları ve sosyal ilişkileri içeren bir fenomendir. Mizahın her zaman neşe, mutluluk gibi olumlu yönlerinin ötesinde eşitsizlik, ayrımcılık gibi olumsuz durumları işaret eden güç ilişkilerine de dikkat edilmektedir.

Çalışmada Yeniköy'deki geleneksel şakalar üzerine değil, durumsal bağlama bağlı olarak aniden, planlanmadan gelişen şakalara odaklanılmaktadır. Bunun amacı belirli bir ortamda ortaya çıkan mizahın arkasındaki sosyal dinamikleri daha iyi anlamaya çalışmaktır. Scott'ın (1985) kavramından yola çıkarak Kuipers'in (2011) ayrıntılı yorumladığ1 şekilde ani gelişen bu mizah ortamları aslında "bir silah, bir saldırı formu, savunma aracı" olma potansiyeli taşır (s. 372). Bu tip doğaçlama ortamlar günlük yaşam gerçekliğinin çok konuşulmayan ama kabul edilmiş anlayışlarında bir çatlak açar ve bu çatlaktan kalıplaşmış anlayışların zıtlıklarını ve eşitsizliği üreten güç ilişkilerine bakmamızı sağlar (Paolucci ve Richardson, 2006, s. 334). Bu çalışmada mizah ile gülme arasındaki ilişkiye de odaklanılmakta ve ikisi arasında birebir bağlantı olmayabileceği kabul edilmektedir (Kuipers, 2011, s. 389). Gülme mizahın, şakalaşmanın amacıdır ama doğal bir sonucu değildir. Şakalaşmanın gülmeye yol açabilmesi, içinde bulunulan durumun paylaşılan tanımı gibi bağlamsal faktörlere ve şaka yapan ile dinleyicileri arasındaki ilişkilere bağlıdır (Zijderveld, 1968; Nielsen, 2011). Dikkatli bir şekilde hazırlanmış bir sahne yerine yaratıcı, planlanmamış ve mevcut duruma göre ortaya çıkan mizah sadece sözel bir şakayı değil, ortamda bulunanlar için anlamlı ve komik olan bir bakışı, bir yüz ifadesini de kapsar. Belirli bir mekânda ve zamanda ortaya çıkan mizah katılımcıları birbirine bağlar, gerçekliği değiştiremese de bir birliktelik ve yük paylaşım hissi verir. Başka bir deyişle, otorite karşısında yüzeysel ve umutsuz bir jest gibi görünse de mizah ve gülme katılımcılar için parçası oldukları hayatın zorluklarıla, gerginlikleriyle, endişesiyle baş etme, bir direniş gösterme imkânı verir.

Mizahın bağlamsal baskılardan kendini korumak için bir başa çıkma taktiği olabilmesini günlük hayatın gizli potansiyelini ve tutarsızlıklarını öne çıkararak günlük yaşam kavramını ustaca problematize eden araştırmacılardan biri olan De Certeau'nun yaklaşımıyla daha iyi anlayabiliriz. De Certeau günlük yaşamın eleştirel bir kavrayışını geliştirirken, sosyal aktörlerin pragmatik davranışlarını tasvir etmenin ötesine geçilmesi konusunda 1srar eder. Yani, günlük yaşam ayrı bir kavram olarak anlaşılamaz, genel sosyal-tarihsel bağlama oturtulmalı ve kurumsal sistem ile bu kurumların kullanıcıları arasındaki güç ilişkileri araştırılmalıdır (Gardiner, 2016, s. 21).

De Certeau'yu diğger günlük hayat araştırmacılarından farklı kılan özelliği günlük hayatın sunduğu direniş olasılığ1nı göstermesidir. Ona göre, günlük hayat akışkan, çoklu ve sembolik olarak yoğun fikirlerin ve hareketlerin heterodoks ve ham bir karışımı olduğu için asimilasyona karşı durmayı becerir (De Certeau, 1984, s. 60). "Taktik" olarak tanımladığ1 güçsüz olanın minik pratiklerinin baskın kurumsal prosedürlerin çatlakları arasında var olmaya devam etmeyi becerebildiğinde 1srar eder (De Certeau, 1984, s. 188-189). De Certeau (1984) taktikleri stratejilerden ayırır. Ona göre stratejiler, kurumsal otoritenin oldukça görünür olan ve belirli bir fiziksel mekânı işgal eden dişavurumlarıdır (s. XIV). Taktikler ise bu tür stabil mekanlardan yoksundur ve resmi olmayan veya marjinal pratiklerdir. Güçlü olanın ayırt edici özelliklerinden olan stratejilerden farklı olarak, taktikler "disiplin ağları içine zaten yakalanmış durumda olan" gruplar veya kişilerin günlük yaşamlarının detaylarında sahiplenilen "eyleme yollarıdır" (De Certeau, 1984, s. XIV). Sosyal kontrol sistemlerinin ve bir disiplin durumunda mevcut bulunan insanlarin stratejilerine odaklanmay1 tercih eden Foucault'dan farklı olarak, De Certeau güçlünün otoritesinin altını kazımak için güçsüzün kullandığı taktikleri anlamaya ve açıklamaya odaklanır. Mizahın kadınların yaşamındaki rolüne odaklanan bu çalışmada köyde erkeklere göre marjinal bir pozisyonda olan kadınların mizahı günlük yaşamlarında ait oldukları baskıcı sosyal ilişkilerden geçici de olsa kurtulmak için ve maruz kaldıkları disiplin prosedürlerini manipüle etmek için saklı bir taktik olarak nasıl kullandıkları gösterilmeye çalışılacaktır. 
De Certeau'nun bir toplumda marjinal durumda olan kişilerin güçlü olanları saklı ve görünmez taktiklerle rahatsız etme becerisindeki anonim yaratıc1lı vurgusu bell hooks'un (1990) "marjinal" kavraminı akla getirir (s. 153). De Certeau gibi hooks da marjinal, güçsüz ve baskı altında olanın her zaman yoksunluk içinde olduğu varsayımını reddeder. Marjin veya kenar, mekân olarak bir baskı alanı olduğu gibi aynı zamanda bir direniş, güç kazanma ve yaratıcilık alanıdır da. hooks marjinal olanın pozisyonunu sadece yoksunluk olarak ve marjinalin bir direniş mekanı olabilme potansiyelini gözden kaçıracak şekilde araştıran araştırmacıları eleştirir. Baskın düzenin güçsüz olana dayattığ1 marjinallik ile güçsüz olanın sahiplendiği ve bir güçlenme ve direniş mekânı olarak kabul ettiği marjinallik arasındaki farkı görmemizi talep eder. hooks (1990), direniş alanı olan marjinali baskı altında olanın hegemonya karşıtı bir söylem ürettiği, yeni varoluş ve hayat biçimleri, alışkanlıkları yarattığ "radikal bir açıklık" olarak tanımlar (s. 218). Yeniköy'de cinsiyet hiyerarşisinde erkeklere göre güçsüz pozisyonda olan kadınlar da pasif, baskıya boyun eğen öğeler değildir ve marjinal pozisyonlarını bir direniş alanına çevirebilecek yaratıcılık performanslanı göstermektedirler. Mizah bu amaçla kullandıkları en güçlü taktiklerden biridir ve onlara yüklenen baskılara yaratıcılıkla karşılık vermelerini sağlamaktadır.

\section{Bulgular \\ Karakterler}

Kuipers (2011) mizahı "mizah düzenleri” olarak tanımlar ve mizah düzenlerinin yazılı olmayan kurallar tarafindan yönetildiğini iddia eder (s. 69). Mesela mizah performansı farklı roller ve pozisyonlar içerir. Bazı kişilerin şaka yapması doğal karşılanır, hatta şaka yapmaları beklenirken, bazı kişiler de dinleyici rolü üstlenirler. Her konu şaka konusu olamaz ve şaka her zaman konuşmayı ve gülmeyi gerektirmez. Şaka bazen de sessizleștirir ve katıllimcilar arasında ayrımlar oluşturur. Aslında mizah ortamları da otorite ortamlarıdır. Bu çalışmada odaklanılan mizah ortamında şaka yapma yetkisi verilen ve hatta kendisinden şaka yapması beklenen kişi Gülnaz'dır. Gülnaz, 63 yaşında, evli, iki çoğundan dört torunu olan bir kadın. Her ne kadar şaka genelde erkekler için kamusal, kadınlar için Özel alan aktivitesi olsa da (Apte, 1985) Gülnaz'in şaka yapma özgürlüğü kamusal alanı da kapsar. Erkeklerin yanında ve çok yakından tanımadığı insanlar arasında dahi şaka yapabilir ve yaptığı şakaları bulunduğu ortama ve dinleyicilerine göre uyarlayabilir. Mesela, ilk tanıştığımız sıralarda yaptığı şakaları bir filtreden geçirip risk almadığ 1 halde sonraki zamanlarda bu filtrelerden vazgeçmişti. Mizahını adapte edebildiğine diğer bir örnek ise bir bayram ziyareti sirasinda evine gelen dünürleriyle sohbette kullandığ1 mizahtır. Şaka yapıp insanları güldürmesine rağmen, yalnız yakın arkadaşı kadınlarla olduğu ortamlarda yaptığı şakalara oranla daha kabul edilebilir, sınırları zorlamayan, müstehcenlik içermeyen şakaları tercih ediyordu. Gülnaz'ın şakacı olarak mahareti ortamı iyi tartmasından ve ortamdaki insanların ne kadar ve nasıl şakayı kaldırabileceğini iyi ölçebilmesinden kaynaklanıyor. Seyircisine göre tavırlarında, ses tonunda, şakalarının içeriğinde yaptığı değişiklikler onun usta bir şakacı olmasını sağlıyor.

Gülnaz'in şaka repertuarının merkezinde küfrün ve müstehcenliğin yer alması onu ilginç kilan özelliklerinden bir diğeri. Ortamda bulunanların yakınlık derecelerine göre derecesi değişen müstehcenlik içeren küfürler edebiliyor. Birilerinin fiziksel özelliklerine, sakarlıklarına, bir şeyi yapış şekline bazen dalga geçme seviyesinde yorumlar yapabiliyor. Gülnaz'ın bu bazen başkalarını yarayabilecek şakaları çevredeki insanlar tarafindan genellikle hoşnutlukla karşılanıyor ve kadınlar arasında uzun süreli gülmelere, şakanın tekrarlanmasına yol açıyor. Tüm bu başarısına rağmen Gülnaz'ın şakalarına müsamaha göstermeyen insanlar da mevcut. Özellikle şakaların içeriğinin ağır küfürler ve müstehcenlik içermesi sadece erkekleri değil bazı kadınları da rahatsız edebiliyor.

Diğer kadınlara kapalı olan, küfür ve müstehcenlik dahi içeren şakacı rolünü ve otoritesini Gülnaz nasıl elde etmiş olabilir? Gülnaz otoritesini k1smen Yeniköy'ün eski ve güçlü bir aileye mensup olmasından alıyor olsa da daha ziyade becerileri, karakteri ve zekâsı onu mahallede sayg1 duyulan bir kadın yapıyor. Sebze-meyve yetiştirme, keçi bakımı, arıcılık, hastalık, ağaç budama, saç kesimi gibi türlü konularda kendisine hem erkekler hem kadinlar sıklikla danışıyor. Ama bu becerilerinden öte olayları, insanları yorumlama ve anlama biçimi de insanı etkileyen bir kadın. Mesela, diğer kadınların ve erkeklerin COVID-19 hakkındaki bilgisi TV kanallarından edindikleriyle sinırlyyken, Gülnaz dünyanın diğer yerlerinde neler olduğundan, hastalığın toplumda nasıl ilerleyeceğinden, alınan önlemlerin eleştirel yorumuna kadar insanı şaşırtan bir farkındalığa sahip. Yüksek sesle konuşması, çabuk sinirlenebilmesi, kocasına karşı küfürlü konuşması da dikkat çeken özelliklerinden biri. Sayılan bu özellikleri Gülnaz'ın özgür ve rahat bir yaşamı olduğu izlenimini verse de uzun dönemli gözlem ve samimi bir mülakatta ortaya çıktığ gibi aslında üzerinde kaldırmakta zorlandığ1 yüklerin baskısı altında olan bir kadın. "Becerikli olmam benim lehime değil aleyhime" diyor; çünkü yakınlarının beklentileri bu yüzden artıyor. Erkek kardeşlerinin şehir dışında olması, kız kardeşinin ise oldukça sorunlu bir evliliğe sahip olmasından dolayı ihtiyar annesi ve felçli babasının tüm ihtiyaçlarını kendisinin görmesi gerekiyor. Bu yardım sadece günlük yaşam ihtiyaçlarını karşılama değil, sahip oldukları zeytinliğin ve tarlaların da bakımını üstlenmesi anlamına 
geliyor. Eşiyle ilişkisinde de mutlu değil. "Dışarıdan sanki patron benmişim gibi görünür ama Hüseyin baş edilmesi çok zor bir adam. Öyle bir inadı vardır ki bağırsam da küfretsem de dediğimi yaptıramam" diye yakınıyor. Üstelik oğlu, eşi ve iki erkek çocuklarıyla beraber üst katta yaşıyor ve dünürleriyle ilişkilerini geren kavga içeren ilişkileri de Gülnaz üzerinde bask1 kuruyor. Hayatındaki anne, eş, evlat, babaanne gibi cinsiyet kimliklerinin talep ettiği görevlerin üzerine bir de günlük yaşamındaki hayvan, bahçe, ev bakımı gibi işler de eklenince "deliresim geliyor" diye yakınıyor.

Tartışma. Eğer cinsiyet rollerini Butler'ın (1999, s. 180) önerdiği gibi devamlı dişa vurulması gereken esas özellikler olarak değil de sosyal ve tarihsel olarak oluşturulan kimlikler olarak düşünürsek, Yeniköy'deki kadınların cinsiyet kimliklerinin günlük yaşamlarında devam eden tekrarlar ile tasdik edildiğini ve dolayısıyla bu kimliklerin performatif olduğunu görebiliriz. İşte Gülnaz küfür de içeren şakalaşma performansları ile toplumsal beklentilerde geçici bir uyuşmazlık yaratabiliyor, hegemonya karşıtı bir söylem üretiyor ve buna rağmen beklentilerin dişına çıkmanın kendisi için bir yaptırımı olmuyor. Diğer bir deyişle, bell hooks'un (1990) ve De Certeau'nun (1984) işaret ettiği sınırlı da olsa bir eylemlilik alanı yaratmış oluyor. Gülnaz bu eylem alanını kendisinden kadın olarak beklenen performansları göstermeyerek yaratıyor ve günlük yaşamda marjinal olan kadın olma konumunu sınırları zorlayarak ve seyircisinden de onay alarak bir eylemlilik alanına dönüştürebiliyor. Mizah Gülnaz için sabit cinsiyet söylemlerini marjinal konumundan bozguna uğratabileceği bir "taktik" işlevi görüyor.

Gülnaz'ın mizah taktiğiyle hegemonik söylemlerde ve beklentilerde bir çatlak açıp bir eylemlilik olasılığ1 yarattığ bu marjinal alandan yararlanan sadece kendisi değil. Bu alana mizahına onay ve kahkahalarla cevap veren diğer kadınlar da dahil oluyorlar. Bu mizah alanı günlük yaşamlarında hissettikleri baskılardan geçici bir süre de olsa özgürleşme imkânı ve mola almalarını sağlıyor. Bu alana gönüllü olarak katılan kadınlardan biri Emine. Emine, Gülnaz'ın tersine utangaç denebilecek bir kadın. 62 yaşında olmasına rağmen sahip olduğu çok sayıda fiziksel rahatsızlığından dolayı bastonsuz yürüyemeyen, evinden dışarı çıkamayan bir kadın. Ama onu asıl bunaltan rahatsızlı̆̆ depresyon ve bu yüzden aldığ1 ağır ilaçların yan etkileri. Etrafınca çok sevilen, yumuşak karakterli Emine'yi günlük yaşantısı içinde gülerken görmek pek mümkün değil. Onu gülerken ve hatta kahkaha atarken görebileceğiniz zamanlar Gülnaz ile beraber olduğu durumlar. Gülnaz'ın şakalarına en çok ve içtenlikle katılan, olumlayan kişi o ve bu ortamları yaratabilmek için çaba harciyor, Gülnaz'in işleri veya diğer sorunlarla uzakta olduğu zamanlarda suskunlaşıyor.
Emine'yi Gülnaz'ın şakalarına bu kadar bağımlı hale getiren sebepleri anlayabilmek için geçmişine, eşi ile ilişkisine bakmak gerekiyor.

Emine fakir bir aileye doğduktan sonra anne ve babası daha iyi bakılacağını umarak onu Yeniköylü uzaktan bir akraba ailenin yanına göndermişler. Öz annesini arada bir görse de evleninceye kadar bu aile yanında kalan Emine 17 yaşında Sinan ile evlendiriliyor. Sinan kendisinden beş yaş büyük ve oldukça otoriter bir eş. Fakat Emine'nin yaklaşık yirmi yılını mutsuzluk içinde geçirmesine sebep olan kişi kayınvalidesi olmuş. Kayınvalidesinin kendisine yaptığı eziyetleri anlatırken hala gözleri dolan Emine "o zamanlar da sessiz, utangaçtım” diyor kendisi için. Üstünde gelin olarak kurulan baskı, ağır iş yükü ve kocasının ilgisizliği Emine için çok yıpratıcı olmuş. İki oğlan çocuğu annesi, hiç bitmeyen beklentiler altında ezilen bir gelin ve kendisine hiç yardımcı olmayan bir erkeğin eşi rollerini y1llarca sürdüren Emine kayınvalidenin ölümüyle eşi ve çocuklarıyla ayrı bir eve taşınıyor. Hayatının bundan sonra biraz rahatlayacağını düşünürken eşinin balmumu dökme işine girmesiyle kendisinden beklenen tüm görevlerin üzerine bir de fiziksel olarak çok ağır bir iş olan balmumu sıkma işi geliyor. Hayatının o dönemini anlatırken çok ağır yükler kaldırmaktan belini sakatladığını, çok çalıştı̆̆ını ama eşine yalvarmasına rağmen sigorta dahi yaptıramamıs olmaktan yakınıyor. Bugün hiçbir geliri yok ve ekonomik açıdan balmumu işinden yüklüce para kazanmış ve emeklilik maaşı alan eşine tamamen bağıml. Parasıyla kendine bir şey aldığını hiç hatırlamıyor. Bugün bile eşi Sinan evin tüm alışverişini yapıyor ve köydeki kadınlar için eğlendirici bir aktivite olan haftalık pazara gelmesine bile izin vermiyor. Sinan çok sinirli ve bu sinirini sadece Emine'ye değil herkese göstermekten çekinmiyor. Emine, Sinan her bağırdığında telaşlanıyor ve öfkesini gidermek için elinden geleni yapıyor. Yemeklerin zamanında hazır olmaması, kaloriferin su kaçırması, tavukların komşu bahçeye kaçması yani her türlü sorun Emine'nin suçu olabiliyor ve karşıllğında kadını korkutan ve onu rencide eden bir öfke patlaması yaşanıyor. Emine gençken eşinden sıklıkla dayak yediğini de söylüyor ve şimdi en azından bu şiddetten kurtulduğuna seviniyor.

Emine'nin hayat1 boyunca katlanmak zorunda kaldığ1 baskıc1, kısıtlı düzen Gülnaz'ın mizahına neden ihtiyaç duyduğunu açıklayabilir. Devamlı riayet, eşinin dayattığı aşağılık hissi, fiziksel ve ruhsal rahatsızlıklarına rağmen hala eksiksiz yerine getirmekle yükümlü olduğu, kendisinin hiç söz hakkının olmadığ1 sorumlulukları Emine'nin günlük yaşamını kısıtlıyor ve kendisine eylemlilik alanı bırakmiyor. Bu alanı yaratabilecek iradeye ve cesarete veya koşullara kendisi sahip olmadığı için Gülnaz'ın mizah yoluyla açtığı alan onun için özgürlügünü bir süre hissedebileceği bir alan 
haline geliyor. Marjinal de olsa özgürlük anları üreten mizah Emine'nin iradesini kullanabildiği, birey olarak var olabildiği bir imkân sunuyor. Özellikle toplumun normlanını sarsan, bir kadının küfür ve müstehcenlik içeren şakalarına gülmek, kahkaha atmak onun için başka türlü elde edemeyeceği, günlük yaşantısının gerçekliğine alternatif bir açıdan bakabilmesini sağlayan bir taktiğe dönüşüyor.

\section{Mizahın yaratımı}

Şimdi içinde Gülnaz'ın, Sinan'ın, Emine'nin ve benimle diğer iki kadının daha bulunduğu bir akşamüstü toplantısında yaşanan şakalaşmalara, bu şakalara tepkilere, bu şakaların farklı algılanış biçimlerine ve sonuçlarına yakından bakalım. Her Cumartesi başka bir kadının evinde olan ev gezmeleri pandemi dolayısıyla sekteye uğrayınca bir araya gelmeler hava müsaade ettiğinde dışarıda yarı-planlı bir hale gelmişti. Ev içi buluşmalarını kesmişler, ev önü bahçelerde çaylı-pastalı buluşmalara devam ediyorlardı. Bu buluşmaların ev içi buluşmalardan en büyük farkı katılanların daha değişken olması, dışarıdan müdahaleye daha açık olmasıydı. Bahsedeceğim çay toplantısı da Eminelerin evinin önündeki bahçede gerçekleşti ve Sinan da bu buluşmaya iki üç bardak çay içip sohbet edecek kadar katıldı. Dışarıdan bir kimse için ev gezmelerinde erkekli-kadınlı oturup sohbet edildiği, kadın-erkek arası şakalaşmanın, kahkaha atmanın hoş karşılandığı bir ortamda insanların keyifli bir buluşması izlenimini veren bu sahneye yakından baktığımızda aslında mizahın eğlencenin ve keyfin ötesinde gergin ilişkiler, dışlama, aşağılama, acı içeren bir ilişkiler ağını açığa çıkardığını görmekteyiz.

Buluşma Gülnaz, Emine, komşu kadınlar Gülayşe ve Naciye ile başlamıştı. Bu ev ziyaretlerinde hâl hatır sorma, günlük gelişmelerden bahsetme dişında asıl sohbet konularını yaşadıkları veya civar köylerdeki tanıdıkların yaptıkları, akrabalık ilişkileri, olaylar, evlilikler gibi konular oluşturuyor. O gün de her zamanki gidişat takip edildi ve bir ara söz Yeniköy'de yaşayan Demirci ailesine geldi. Bu aile erkek çocuklarını yeni evlendirmişlerdi ve misafirlikteki kadınlar düğünün ve gelinin ailesini ayrıntılı olarak analiz ettikten sonra dügünde kullanılan plastik masa ve sandalyeler sohbetin ana konusu oldu. Gülnaz ve ailesi diğer birçok işin yanında köydeki dügünlere plastik masa ve sandalye kiralama işini de yürütüyorlar. $\mathrm{Bu}$ dügün için de malzemeleri onlar kiralamışlardı ve dügün bitince sandalyelerden bir kısmının kırık ve iki tanesinin eksik olduğu anlaşllınca Gülnazlar ile Demirci ailesi arasında sorun yaşanmıştı. Bu gerginlik içeren ve hala tatlıya bağlanmamış olay belli ki Gülnaz’ı çok geriyordu. Her zamankinden daha sik sinirleniyor, bağırıyor ve insanları bozuyordu.

Gülnaz en ciddi olayları bile anlatırken geniş iletişim yöntemleri yelpazesi kullanarak mizahı performatif bir şekilde kullanmayı becerebilen bir kadın. Kullandığı dil, sözcük oyunları, jestler, ses tonu, bakışları, görsel betimlemeler, durum değerlendirmeleri bir bütünlük içinde etrafindakilerde eğlenceli bir sunu oluşturuyor ve asil esprisini yapana kadar zaten insanlar gülmeye, kıkırdamaya veya gülümsemeye başlamış oluyorlar. Bu noktada diğer mizah çalışmalarında da söz konusu olan bir noktaya dikkat çekmek gerekebilir. Mizah içeren durumları, vakaları anlatırken tekrarlanan "komik olduğunu anlaman için orada olman gerekirdi" burada da geçerli bir durum ve mizahın içinde yer alan kişiler için eğlendirici olan okuyucu için anlamsız gelebilir. Mizahın olma anı ile aktarımı arasındaki uyuşmazlık mizahın belirli bir durumda var olan sosyal ve insanlar arası koşullara bağlı olan hassas, kırılgan bir fenomen olmasindan kaynaklaniyor (Pollio, 1985, s. 228). Pollio (1985), gülmek için "orada olman gerekirdi" saptamasının mizahın gerçekleşmesi için zihinsel bir taahhüt ve bedensel bir katılım şartı gösterdiğini de isabetli bir şekilde söyler (s. 229). Bu özellikler mizahın tek başına değil içinde gerçekleştiği sosyal ilişkiler, güç dengeleri ile değerlendirilmesi gerektiğini bir kez daha gösterir. Buna dayanarak, söz konusu durumda da Gülnaz'ın mizahının komik ve eğlendirici olduğunu kanıtlamak amaçlanmamaktadır ki zaten bu mümkün değildir. Burada mizahın hangi koşullarda, neden oluştuğunu, nasıl paylaşıldığını, kimi nasıl etkilediğini, sonuçlarının ne olduğunu incelemek amaçlanmaktadır.

Dügün sonrası yaşanan plastik masa ve sandalyelerle ilgili gerginliği anlatacağı belli olan Gülnaz sözüne düğünden değil düğün sahibi ailenin geçmişini, ilişkilerini, davranışlarını hafif alaya alarak başladı. Bunları benim dışımda mevcut bulunan insanlar zaten bilmelerine ve muhtemelen Gülnaz'dan önceden de dinlemiş olmalarına rağmen gülümseme ve hafif gülmelerle dinliyorlardı. Gülnaz özellikle damadın annesini hedef almıştı. Çocuklarını kötü yetiştirmiş olmasından, aslında elinden hiçbir iş gelmemesinden, yaptığ 1 işlerin elle tutulur şeyler olmamasından, yaptı̆̆ ekmeğin bile kabarmadığından, oğlunu evlendirdiği kızı da yanlış seçmiş olmasından araya espriler ve müstehcen sıfatlar katarak ve ses tonunu, jestlerini yaratıcı bir şekilde kullanarak uzun uzun anlatt1. Bu konuşmanın orta yerlerinde çay içmek için Sinan da katıldı ve herhangi bir yorum yapmadan Gülnaz'1 sakin bir şekilde dinlemeye başladi. Uzun girişten sonra Gülnaz asıl meseleye yani düğünde Demirci ailesi ile aralarında gerçekleşen gerginliğe geldiğinde Sinan araya girdi ve anlaşmayı yanlış yaptıklarını, kayıp ve zarar durumunda ne yapılması gerektiğini düğün öncesi konuşmuş olmaları gerektiğini söyleyince Gülnaz aniden ciddileşti. Birkaç saniyelik dinleyicilerin de eşlik ettiği sessizlik sonrasında 
Sinan'ın iki yıl önce başına gelen utandırıcı bir olayı hatırlattı. Bu olayda Sinan zeytinlerini Yeniköylülerin tercih ettiği zeytin sıkma fabrikası yerine fiyatının daha ucuz olduğunu iddia ettiği başka bir köydeki fabrikaya götürmüştü. Fakat sıkımda elde ettiği yağa Yeniköylülerin ödediğinin neredeyse iki katı ödediğini çok sonradan fark etmişti ve olay köyde duyulup Sinan'ın olmadığı ama farkında olduğu sohbetlerin alay konusu olmuştu. Gülnaz bu olaya gönderme yaparak "Evet Sinan, aklımıza gelseydi seni çağırırdık, bize şöyle kârlı bir anlaşma yapardın" deyince herkes siniriyle meşhur Sinan'ın ne tepki vereceğini bekledi. Fakat Sinan sessiz kalmayı tercih ederken kadınlar ama özellikle de eşi Emine kahkahalarla gülmeye başladılar. Gülnaz ciddi bir şekilde konuşmasını sürdürürken Emine hala vücudu sarsılacak şekilde ama sessizce gülmeye devam ediyordu. Olayın ayrıntılarını bitirip dügün sahibi kadınla aralarında geçen son konuşmayı da kadının adının önüne türlü küfürler getirerek komik bir şekilde anlattıktan sonra konuşmasını kadına buraya yazılamayacak bir müstehcenlik içeren, kadının cinselliğini aşağılayan bir küfürle bitirdi. Sinan hala duymamış gibi yaparken diğer tüm kadınlar yüksek sesli kahkahalarla gülüyorlardı. Ama aralarında en şiddetli ve kesintisiz gülen Emine idi. Gülnaz, yine cinsiyetçi küfürler ederek söz konusu kadına söylendikten sonra çayından son bir yudum alıp keçilerini sağma bahanesiyle kimseyle vedalaşmadan ayrıldı. Ayrilmasından sonra diğer kadınlar bir süre daha olay hakkında yorumlar yapıp gülerek konuşurken Sinan da çayını bitirip kalktı ve içeri girdi.

Tartışma. Tasvir edilen bu vakada günlük yaşamında bir kadının (Gülnaz) başka ailelerle gerginlik yaşamalarına sebep olan bir olayı diğer kadınlarla eğlenceli bir şekilde paylaşmasına tanık oluyoruz. Her ne kadar Sinan da mevcut olsa da hitap edilen, iletişim kurulan o değil, diğer kadınlar. Zaten Sinan'ın araya girmesi de hoş karşılanmadı ve görmezden gelindi ve hatta dişland. Gülnaz olayı mizahla anlatıyor olsa da aslında bu olay iki aile arasında ciddi bir soruna yol açmıştı. Aile üyeleri arasında birbirlerinin evlerine gidip bağrışmalar, çarşıda dalaşmalar, mahkemeye verme tehditleri gibi olaylar yaşandı. Canını uzun bir süre sıkan bu olayı Gülnaz'ın mizahi anlatıyor olması ve diğer kadınların da buna gülerek onay vermesi kadınlar ile sosyal bir dayanışma ve birbirini teyit etme yoluyla olayın daha baş edilebilir olmasını sağlıyor olabilir. Van Roekel'in (2016, s. 63) Buckley'e atıfla dediği gibi başkalarıyla yapılan gülme eylemi, yapılan bir espriye ortak gülme yoluyla onay verme belirli bir konuda bir görüş açısını (bu durumda kavgada Gülnaz'n haklı olduğunu) kabulün sembolik bir biçimidir ve sonucunda bir çeşit dayanışma inşa eder. Aynı zamanda, Gülnaz'ın kendisinin haklılı̆̆ını ortak bir gülme tepkisiyle almış olması onun için bu kadınların arkadaşlıklarını teyit edebileceği, onlara güvenmeye devam edebileceği anlamına geliyor olabilir.

Arkadaş grubundaki bir kadına eziyet eden bir erkeğin de mizah ortaminda bulunmasina rağmen muhatap alınmaması ve hatta dişlanması bize mizahın birleştirici olduğu kadar dışlayıcı olabileceğinin de bir göstergesi. Carty ve Musharbash (2008, s. 214), gülme eyleminin gülmeyi paylaşanlar ile "diğerleri" arasında bir sınır çizdiğini söyler. $\mathrm{Bu}$ kadınları birbirine bağlayan sadece mizahın paylaşımı değil aynı zamanda kendileri ile Sinan ve kavgalı olunan kadin arasında oluşturulan mesafe de oluyor. Günlük güç dengelerinde kesin bir otoritesi olan Sinan'ın Gülnaz'in kendisini hedef alan iğneleyici esprisine tepkisini nasıl anlayabiliriz? Sinan'ın bu şakayı duymazlıktan gelmesi ve gülüşmelere katılmaması mizahın herkes tarafından aynı şekilde paylaşılmadığını ve herkes için memnun edici olmadığını gösteriyor (Seizer, 1997). Kendisini hedef alan şakaya gülümseyerek veya kızarak tepki vermek yerine duymazlıktan geliyor. Özellikle üzerinde keskin bir tahakküm kurduğu eşinin hararetli gülmüss olmasını fark etmiş olmalı. Sonradan Emine'ye sorulduğunda evde de kendisine bu konuyla ilgili bir şey söylemediğini söyledi. Kuipers'in (2011) dediği gibi, yapılan mizaha nasıl tepki verileceği güç dinamiklerine, hedefteki kişinin statüsüne bağlıdır ve duymazlıktan gelmek gücü az olanların tepkisidir (s. 72-73). Şakaya karş1lık vermek ise güç ve güven ister. Sinan'ın günlük yaşamında kurduğu otoritenin bu mizah ortamında işe yaramadığını görüyoruz. Bu ortamın güç hiyerarşisinde Gülnaz ve diğer kadınlar, ama özellikle de karısı daha güçlü durumda. Tabii ki mizah ortamı sona erdiğinde günlük yaşam eskisi gibi devam ederken Emine ile Sinan arasındaki güç dengeleri ikincisinin lehine değişecek, kalıcı bir değişiklik olmayacak. Ama bu mizah tarafından yaratılan marjinal özgürleşme alanında Emine bir mola alabiliyor. Mizah bu kadınlar için sosyal beklentilerin ve baskıcı güç ilişkilerinin ötesine geçmelerine geçici de olsa olanak sağlıyor.

Emine'nin kendisini hor gören eşine karşı yapılan bu şakaya daha çok gülmesine de daha yakından bakmak gerekir. Bu gülme sadece gülümseme değil, yüksek kahkahanın eşlik ettiği ve vücudunun sarsılmasına sebep olan şiddetli bir "patlama” anıydı. Emine, günlük hayatında tecrübe ettiği diğer insanlar, toplum, zaman ve hatta kendi bedeni tarafindan dayatılan kisitlamalardan geçici bir kurtulma tecrübesi yaşadi. Rahatlama teorilerinin iddia ettiği gibi Emine mizah alanına girdiği andan itibaren hazır gerçeklikten kopuyor ve normal zamanda devamlı denetimde tuttuğu bilinçdışına ve denetleme mekanizmasina mola aldırıyor. Elbette Emine'nin mizah ile oluşturulan bu özgürlük alanından ayrılınca aynı bedene, aynı topluma, aynı güç ilişkilerine geri döneceği, uzun dönemli bir etkisinin olmadığı iddia 
edilebilir. Daha da ileri gidilerek, Gülnaz'ın husumetli olduğu kadını eleştirirken cinsiyetçi müstehcenliğe başvurması, diğer kadınların da bunu gülerek onaylaması kendilerini marjinalize eden cinsiyet normların, cinsellik anlayışlarını tekrarladıkları ve tekrar üretmiş oldukları şeklinde bile yorumlanabilir. Bu olası güçsüz hatta zarar verici etkilerine rağmen mizahın bu kadınlar için Mary Douglas'in (1968) dikkat çektiği daha uzun dönemli ve sistem için bozguncu bir etkisi olduğunu da dikkate almak gerekiyor. Mizah kadınlar için gerçekliğe farklı bir açıdan bakmalarını sağlayan bir "taktik", bir "güçsüzün silahı" işlevini görüyor (Scott, 1985). Otorite ile direkt bir yüzleşme değil, dolaylı bir ilişki kurmalarını sağlarken zorlu hayat koşullarına devam edebilmelerini sağlayan farklı bir gerçekliğin mümkün olma ihtimalini hatırlatıyor. Sosyal düzen üzerindeki otoritenin gücünü geçici süreliğine kaldırsa da kadınlar arasındaki ortak bir var olma bilincini paylaşmaktan beslenen bağ1 ve saygiy1 güçlendiriyor. Emine için Sinan tiran olarak kalmaya devam edecek olsa da onun gücünü harfiyen kabul etmeyi reddediyor ve bu kadar gülerken tamamen güçsüz olamayacağını hissediyor. Mizah, kadınların hayatlarında marjinal de olsa bir özgürlük alanı yaratıyor.

\section{Sonuç}

Günlük yaşamda mizahın üretilme ve tüketilme biçimlerine odaklanan bu çalışmada öncelikle yaklaşık son kırk yıl içerisinde geliştirilmiş ve antropologlar tarafindan mizah çalışmalarında kullanılan teoriler tanıtılmış ve Türkçe mizah çalışmalarının faydalanabileceği geniş bir kaynak paylaşımı yapılmıştır. Bu ilk bölümün amacı mizahın sadece kültürel bir öğe değil, bir topluluktaki ortak anlayışları ve sosyal ilişkileri içeren bir fenomen olduğunu göstermektir. Ayrıca mizahın antropolojik analize uygun olduğuna ve başlı başına zengin bir araştırma konusu olması gerektiğine dikkat çekilmeye çalışılmışır. İkinci bölümde ise incelenen teorilerden esinlenilerek ama mizahın günlük yaşamdaki rolünün daha ayrıntılı incelenmesini sağlayan bir teorik çerçeve çizilmiş ve sonrasında bu çerçeve içinde Muğla kentinde bulunan Yeniköy'de kadınlar arası mizah ilişkileri sosyal ve güç ilişkileri içinde devam eden günlük yaşam bağlamında incelenmiştir. İki kadının hayatına odaklanilarak mizahın bu kadinların yaşamlarındaki anlamı ve işlevi açıklanmıştır. Ayrıca mizahın günlük yaşam içinde plansız gelişirken aslında kadınların içinde var oldukları cinsiyet ve güç ilişkileri gibi daha genel konulara 1şı tutan işlevinin ön plana çıtığ1 bir buluşma analiz edilmiştir. Yapılan inceleme göstermektedir ki kadınlar arası mizah ilişkileri sosyal ve güç ilişkileri içinde devam etmektedir ve mizah marjinal bir pozisyonda bulunan kadinlar tarafindan yaratıcı bir direniş taktiği olarak kullanılmaktadır. Mizahın kadınların günlük yaşamlarında etkili olan otorite, statü ve cinsiyet gibi kısıtlayıcı ve hatta şiddet içeren ilişkiler ile başa çıkma taktiği olduğu iddia edilmiştir. Mizahın sosyal bağlamlardaki çok sayıdaki boyutları, biçimleri ve işlevleri bu çalışmanın sunabildiğinden çok daha karmaşı ve çeşitlidir. Farklı mekanlarda ve anlarda mizahın insanlar tarafindan yaratıcı şekillerde kullanılma biçimlerini inceleyecek olan etnografik çalışmalara ihtiyaç vardır. Çünkü mizah ile insan varoluşu birbirlerine oldukça karmaşık şekillerde bağlıdır ve mizah sosyalkültürel gerçekliğin sosyal durumları ve etkileşimleri etkileyen önemli bir parçasıdır.

\section{Kaynakça}

Apte, M. (1985). Humour and laughter: An anthropological approach. Cornell University Press.

Apte, M. L. (1988). Disciplinary boundaries in humorology: An anthropologist's ruminations. Humor, 1(1), 5-25. https://doi. org/10.1515/humr.1988.1.1.5

Beckett, J. (2008). Laughing with, laughing at among Torres Strait Islanders. Anthropological Forum, 18(3), 295-302. https://doi. org/10.1080/00664670802429412

Billig, M. (2005). Langhter and ridicule: Towards a social critique of bumour. Sage.

Boyer, D., ve Yurchak, A. (2010). American stiob: Or, what latesocialist aesthetics of parody reveal about contemporary political culture in the West. Cultural Anthropology, 25(2), 179221. https://doi.org/10.1111/j.1548-1360.2010.01056.x

Butler, J. (1999). Gender trouble: Feminism and the subversion of identity. Routledge.

Cardeña, I., ve Littlewood, R. (2006). Humour as resistance: Deviance and pathology from a ludic perspective. Anthropology and Medicine, 13(3), 285-296. https://doi. org/10.1080/13648470600863613

Carty, J., ve Musharbash, Y. (2008). You've got to be joking: Asserting the analytical value of humour and laughter in contemporary anthropology. Anthropological Forum, 18(3), 209217. https://doi:10.1080/00664670802429347

Colla, E. (2013). In praise of insult: Slogan genres, slogan repertoires and innovation. Review of Middle East Studies, 47(1), 37-48. https://doi.org/10.1017/S2151348100056317

Critchley, S. (2011). On humour. Routledge. https://doi. org/10.4324/9780203870129

Dağtaş, M. S. (2016). 'Down with some things!' The politics of humour and humour as politics in Turkey's Gezi protests. Etnofoor, 28(1), 11-34. https://www.jstor.org/stable/43823940

De Certeau, M. (1984). The Practice of everyday life. University of California Press.

Dinç, E. (2012). On the limits of oppositional humor: The Turkish political context. Middle East Journal of Culture and Communication, 5(3), 322-337. https://doi.org/10.1163/18739865-00503012

Douglas, M. (1968). The social control of cognition: some factors in joke perception. Man, 3(3), 361-376. https://doi. org $/ 10.2307 / 2798875$

Douglas, M. (1975). Implicit meanings: Essays in anthropology. Routledge. Driessen, H. (2016). Afterword: Humour matters. Etnofoor, 28, 141 - 
146. https://www.jstor.org/stable/43823947

Dundes, A. (2017). Cracking jokes: Studies of sick humor cycles and stereotypes. Quid Pro Books.

Dwyer, K. (2009). Geertz, humour and Morocco. Journal of North African Studies, 14(3-4), 397-415. https://doi. org/10.1080/13629380902924059

Eken, B. (2014). The politics of the Gezi Park resistance: Against memory and identity. South Atlantic Quarterly, 113(2), 427-436. https://doi.org/10.1215/00382876-2644212

Eker Öğüt, G. (2009). Insan Kültür Miæah, 1. Basım. Grafiker Yayınlar1.

Fine, G. A. (1985). Sociological approaches to the study of humor. D. L. F. Nilsen, P. E. McGhee ve J. H. Goldstein (Ed.) içinde, Handbook of bumor research (s. 159-181). Springer. https://doi. org/10.1007/978-1-4612-5572-7 8

Freud, S. (1963). Jokes and their relation to the unconscious. P. Gay (Trans.). W. W. Norton. (Özgün eserin basımı 1905).

Gardiner, M. (2016). Gündelik hayat eleștirileri. Heretik Yayınları.

Goldstein, D. M. (2013). Laughter out of place: Race, class, violence, and sexuality in a Rio shantytown. University of California Press. https://doi.org/10.1525/9780520955417

Görkem, S.. Y. (2015). The only thing not known how to be dealt with: Political humor as a weapon during Gezi Park Protests. Humor, 28(4), 583-609. https://doi.org/10.1515/ humor-2015-0094

Graeber, D. (2009). Direct action: An ethnography. AK press.

Gürcan, E., ve Peker, E. (2015). Challenging neoliberalism at Turkey's Gezi Park: From private discontent to collective class action. Springer. https://doi.org/10.1057/9781137469021

Gürel, P. (2015). Bilingual humor, authentic aunties, and the transnational vernacular at Gezi Park. Journal of Transnational American Studies, 6(1). https://doi.org/10.5070/T861019932

hooks, b. (1990). Yearning: Race, gender, and cultural politics. South End Press.

Kuipers, G. (2011). The politics of humour in the public sphere: Cartoons, power and modernity in the first transnational humour scandal. European Journal of Cultural Studies, 14(1), 63 80. https://doi.org/10.1177/1367549410370072

Lewis, P. (2006). Cracking up: American bumor in a time of conflict. University of Chicago Press.

Lockyer, S., ve Pickering, M. (2008). You must be joking: The sociological critique of humour and comic media. Sociology Compass, 2(3), 808-820. https://doi.org/10.1111/j.17519020.2008.00108.x

Makar, F. (2011). 'Let them have some fun': Political and artistic forms of expression in the Egyptian revolution. Mediterranean Politics, 16(2), 307-312. https://doi.org/10.1080/13629395.2 011.583755

Musharbash, Y. (2008). Perilous laughter: Examples from Yuendumu, Central Australia. Anthropological Forum, 18(3), 271-277. https://doi.org/10.1080/00664670802429388

Nielsen, M. M. (2011). On humour in prison. European Journal of Criminology, 8(6), 500-514. https://doi. org/10.1177/1477370811413818
Osella, C., ve Osella, F. (1998). Friendship and flirting: Micropolitics in Kerala, South India. Journal of the Royal Anthropological Institute, 4(2),189-206. https://doi.org/10.2307/3034499

Paolucci, P., ve Richardson, M. (2006). Sociology of humor and a critical dramaturgy. Symbolic Interaction, 29(3), 331-348. https:// doi.org/10.1525/si.2006.29.3.331

Pollio, H. R. (1985). Notes toward a field theory of humor. Paul E. McGhee ve Jeffrey H. Goldstein (Ed.) içinde, Handbook of bumor research (s. 213-230). Springer. https://doi. org/10.1007/978-1-4612-5572-7 10

Scott, J. C. (1985). Weapons of the weak: Everyday forms of peasant resistance. Yale University Press.

Seizer, S. (1997). Jokes, gender, and discursive distance on the Tamil popular stage. American Ethnologist, 24(1), 62-90. https://doi. org/10.1525/ae.1997.24.1.62

Trnka, S. (2011). Specters of uncertainty: Violence, humor, and the uncanny in Indo-Fijian communities following the May 2000 Fiji coup. Ethos, 39(3), 331-348. https://doi.org/10.1111/ j.1548-1352.2011.01196.x

Türkmen, F. (2019). Mizah-fikra ve katmerli fikralar. 9. Milletlerarası Türk Halk Kültürü Kongresi Bildirileri, 419-426. https://www.kulturportali.gov.tr/mrepo/eKitap/ebMizahfikravekatmerli/

van Roekel, E. (2016). Uncomfortable laughter: Reflections on violence, humour and immorality in Argentina. Etnofoor, 28(1), 55-74. https://www.jstor.org/stable/43823942

Zijderveld, A. C. (1968). Jokes and their relation to social reality. Social Research, 35(2), 286-311. https://www.jstor.org/ stable/40969908

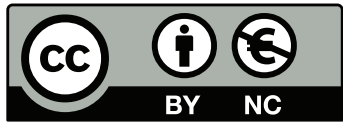

2021. Telif haklar1 yazar(lar)a aittir.

Bu makale Creative Commons Atıf-GayriTicari 4.0 Uluslararası (CC BY-NC 4.0 lisansının hüküm ve şartları altında yayımlanan açık erişimli bir makaledir. 